\title{
Towards stereochemical control: A short formal enantioselective total synthesis of pumiliotoxins 251D and 237A
}

\author{
Jie Zhang ${ }^{1}$, Hong-Kui Zhang ${ }^{* 1}$ and Pei-Qiang Huang ${ }^{* 1,2}$
}

\section{Full Research Paper}

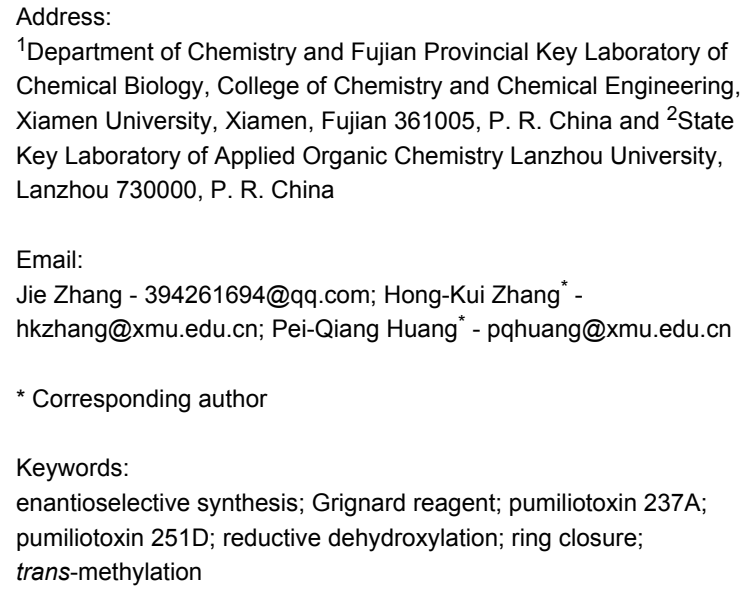

${ }^{1}$ Department of Chemistry and Fujian Provincial Key Laboratory of Chemical Biology, College of Chemistry and Chemical Engineering, Xiamen University, Xiamen, Fujian 361005, P. R. China and ${ }^{2}$ State Key Laboratory of Applied Organic Chemistry Lanzhou University, Lanzhou 730000, P. R. China

Email:

Jie Zhang - 394261694@qq.com; Hong-Kui Zhang* -

hkzhang@xmu.edu.cn; Pei-Qiang Huang* - pqhuang@xmu.edu.cn

${ }^{*}$ Corresponding author

Keywords:

enantioselective synthesis; Grignard reagent; pumiliotoxin 237A;

pumiliotoxin 251D; reductive dehydroxylation; ring closure;

trans-methylation

Open Access

Beilstein J. Org. Chem. 2013, 9, 2358-2366.

doi:10.3762/bjoc. 9.271

Received: 26 August 2013

Accepted: 10 October 2013

Published: 05 November 2013

This article is part of the Thematic Series "Natural products in synthesis and biosynthesis".

Guest Editor: J. S. Dickschat

(C) 2013 Zhang et al; licensee Beilstein-Institut.

License and terms: see end of document.

\begin{abstract}
A concise enantioselective synthesis of the advanced intermediate 5 for the synthesis of pumiliotoxins (Gallagher's intermediate) is described. The synthesis started from the regio- and trans-diastereoselective $(\mathrm{dr}=98: 2)$ reductive 3-butenylation of $(R)$-3-(tertbutyldimethylsilyloxy)glutarimide 14. After $O$-desilylation and Dess-Martin oxidation, the resulting keto-lactam 10 was subjected to a highly trans-stereoselective addition of the methylmagnesium iodide to give carbinol $\mathbf{1 1}$ as sole diastereomer. An efficient ring closure procedure consisting of ozonolysis and reductive dehydroxylation provided the indolizidine derivative $\mathbf{5}$, which completed the formal enantioselective total synthesis of pumiliotoxins 251D and 237A.
\end{abstract}

\section{Introduction}

Pumiliotoxins (PTXs, 1, Figure 1) such as pumiliotoxin 251D (2) are a subclass of indolizidine alkaloids isolated from the skin secretion of neotropical frogs. A total of 19 members have been isolated and partially characterized [1]. Pumiliotoxins are structurally characterized by a ( $Z$ )-6-alkylidene-8-hydroxy-8methylindolizidine ring system, which distinguishes from one to another by the 6-alkylidene side chain [1]. Interestingly, it is known that poison frogs don't produce the alkaloids themselves, instead, they accumulate alkaloids from dietary alkaloidcontaining arthropods serving as a chemical defense against predators. It is not surprising that the alkaloids found in poison frogs can also be detected from ants, and most of them show remarkable bioactivities [2,3]. For example, formicine ants have been shown to be an arthropod source of the pumiliotoxin alka- 


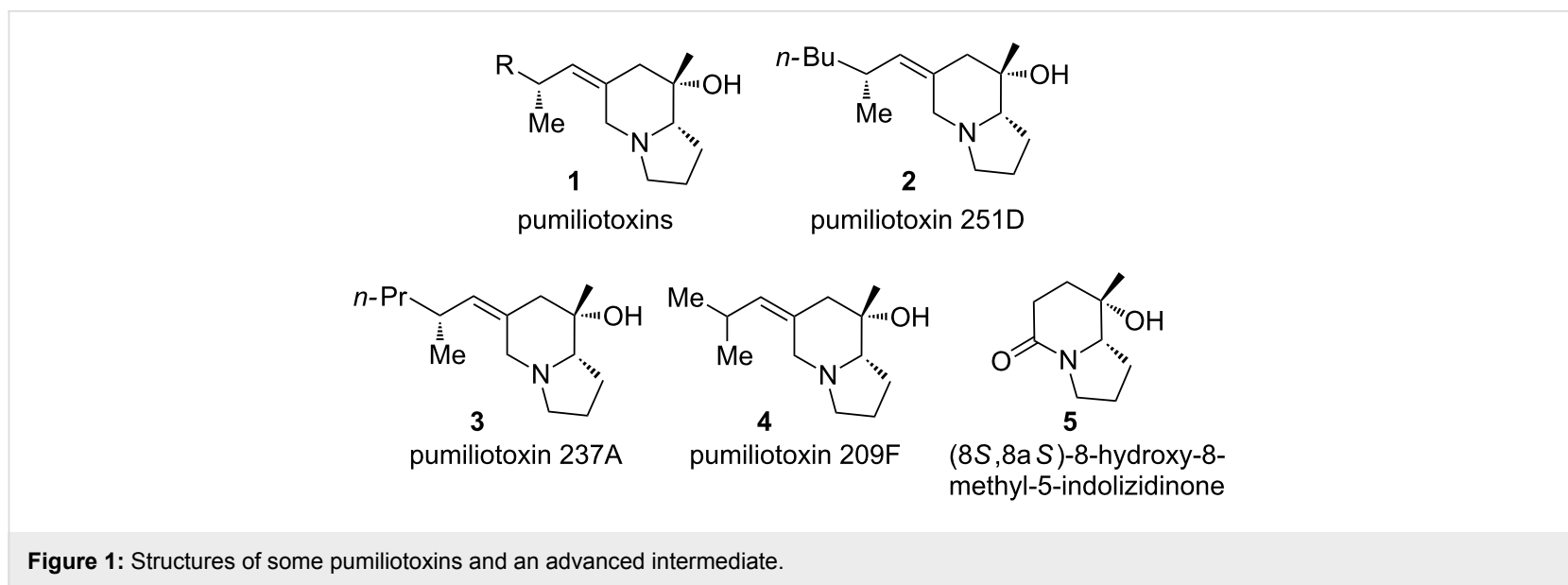

loids of dendrobatid poison frogs [4,5]. Forthermore, from the extracts of an unidentified Scheloribates $s p$. of mites, pumiliotoxin 237A (3) was detected as a minor component [6]

That the wide range of biological activities possessed by these molecules have attracted much attention of synthetic organic chemists, and numerous approaches have been reported [7-9] Pumiliotoxin 251D (PTX 251D) (2) is the first structurally defined member of pumiliotoxins, a class of dendrobatid alkaloids isolated from Ecuadorean poisonous frog, Dendrobares tricolor in 1980 [10]. Since the pioneering work of Overman [11], a number of approaches have been developed for the synthesis of PTX 251D [12-26]. Among them, that of Gallagher [12] has attracted much attention. They demonstrated that $(8 S, 8 \mathrm{a} S)$-8-hydroxy-8-methyl-5-indolizidinone (5, Figure 1$)$ can serve as an advanced intermediate for the synthesis of pumiliotoxin 251D [12]. Later on, Nubbemeyer and co-workers used the Horner olefination to convert $\mathbf{5}$ and its diastereomer into (+)-PTX 251D (2) and the 8-epimer of PTX 209F (4), respectively [17]. Recently, $(8 S, 8 \mathrm{a} S)-5$ has been used for the synthesis of PTX 237A (3) [6]. Thus, it is logic to envision that an efficient synthesis of this key intermediate would allow access to other member of pumiliotoxins and their analogues. To date more than ten synthetic approaches to $(8 S, 8 \mathrm{a} S)-5$ have been published [12-15,18-22,27-31], among them L-proline and its derivative were used as popular precursors from the pool of chiral compounds [13-15,18-22]. Herein, we report a concise diastereoselective synthesis of $(8 S, 8 \mathrm{a} S)-\mathbf{5}$ starting from $(R)-3-$ (tert-butyldimethylsilyloxy)glutarimide 14, a versatile building block developed from our laboratory [32].

\section{Results and Discussion}

In recent years, we have been engaged in the development of efficient methodologies for the synthesis of nitrogen-containing bioactive heterocycles [33-37], and recently reported an approach for the synthesis of $(8 R, 8 \mathrm{a} S)$-8-hydroxy-5-indolizidi- none (6) [38]. As a continuation of that study, the synthesis of $(8 S, 8 \mathrm{a} S)-\mathbf{5}$ starting from compound $\mathbf{6}$ was envisioned. For this purpose, alcohol 6 was subjected to Swern oxidation (DMSO, $(\mathrm{COCl})_{2}, \mathrm{iPr}_{2} \mathrm{NEt},-78$ to $\left.0{ }^{\circ} \mathrm{C}, 3 \mathrm{~h}\right)$, and the resulting ketolactam 7 treated with MeMgI in diethyl ether $\left(-78\right.$ to $\left.0^{\circ} \mathrm{C}, 1 \mathrm{~h}\right)$, which gave alcohols $\mathbf{5 / 5} \mathbf{a}$ as an inseparable mixture of diastereomers in a ratio of 1:2.2 (combined yield: $47 \%$ over 2 steps) (Scheme 1). A comparison of spectral data $\left({ }^{1} \mathrm{H}\right.$ and ${ }^{13} \mathrm{C}$ NMR) of our products $\mathbf{5 / 5}$ a with those reported [12,22,28] showed that the desired $(8 S, 8 \mathrm{a} S)-\mathbf{5}$ was the minor diastereomer. Similar results have been reported by Nubbemeyer [27] and $\mathrm{Li}$ [8]. In view of the fruitless efforts of Nubbemeyer [27] and $\mathrm{Li}$ [8] in inversing the diastereoselectivity of the methylation reaction of keto-lactam 7, an alternative approach was envisaged.

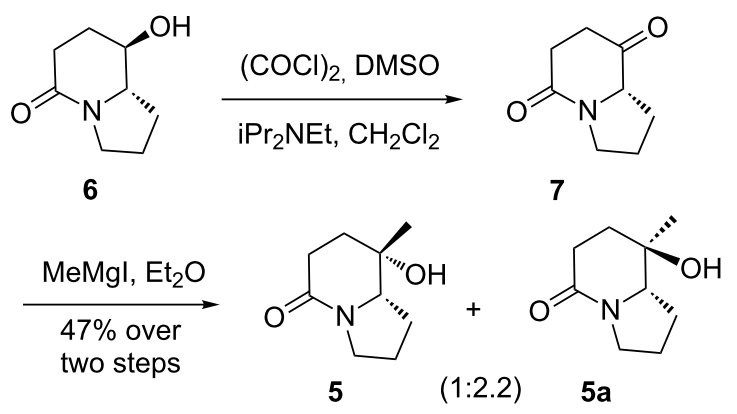

Scheme 1: Synthesis of 5 from 6 via oxidation-addition sequence.

To develop a diastereoselective approach to $(8 S, 8 \mathrm{a} S)-\mathbf{5}$, it would be helpful to analyze the plausible stereochemical course of the methylation of keto-lactam 7. The observed unusual stereoselective cis-methylation implicates a preferential axial attack of the methylmagnesium iodide to the bicyclic keto-lactam 7 (Scheme 2). Although the preferential axial attack of "small" nucleophiles to cyclohexanone is well known [39-41], the "small" nucleophiles are limited to some metallo-hydrides, 


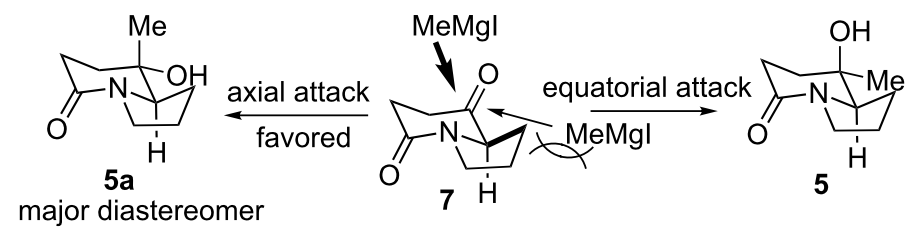

Scheme 2: Plausible stereochemical course of the preferential axial addition of methylmagnesium iodide to bicyclic keto-lactam 7.

metallo-acetylenide [42] and (cyanomethyl)lithium [43]. In the case of bicyclic keto-lactam 7 , presumably, the equatorial attack of methylmagnesium iodide to give $\mathbf{5}$, suffers from unfavorable eclipsing interactions between the incoming methylmagnesium iodide and the vicinal methylene group. As a consequence, the axial attack to give $\mathbf{5 a}$ is more favorable.

It was envisioned that if a monocyclic keto-lactam was used, the situation would be changed and an equatorial attack of the nucleophile giving the cis-product would be preferable. Indeed, Holmes and co-workers have reported that methylmagnesium bromide addition to $\mathrm{N}$-Cbz-protected piperidin-3-one 8 produced exclusively the trans-methylation product 9 [44] (Scheme 3). In that case, the $N$-benzyloxycarbonyl group imposed $\mathrm{A}^{1,3}$-strain on piperidine derivatives founded the basis for the observed stereocontrol.<smiles>CCCCO[C@H]1CCN(C(=O)OCc2ccccc2)[C@H](CCCO)[C@]1(C)O</smiles>

Scheme 3: Holmes' exclusive trans-diastereoselective methylation of $\mathrm{N}$-Cbz-protected piperidin-3-one 8.

Thus, we chose keto-lactam $\mathbf{1 0}$ as our substrate. Although compound $\mathbf{1 0}$ is not a urethane, and a $\mathrm{A}^{1,3}$-strain not longer exists, a simple chair conformational-controlled preferential equatorial attack could be expected (Scheme 4). Substrate 10 may adopt two plausible chair conformations $\mathbf{1 0 a}$ and $\mathbf{1 0 b}$, in which conformation $10 \mathbf{b}$ with a pseudoequatorially positioned $N$ - $\alpha$-substitutent is more stable. Thus, the pseudoequatorial attack of MeMgI would be preferential, which gives the product $\mathbf{1 1}$ as the major product.

On the basis of the abovementioned analysis, a retrosynthetic analysis of $(8 S, 8 \mathrm{a} S)-5$ is displayed in Scheme 5 , which features the formation of the fused pyrrolidine ring from the but-3-ene1-yl group, the expected trans-diastereoselective methylation as the key step, and protected $(R)$-3-hydroxyglutarimide-based regio- and trans-diastereoselective reductive alkylation, a synthetic methodology developed from our laboratory $[32,38,45,46]$, as the starting point.

Our synthesis started from the addition of a freshly prepared 3-butenylmagnesium bromide to imide 13 [47] in dichloromethane at $-78^{\circ} \mathrm{C}$ for $3 \mathrm{~h}$, which gave regioselective carbinol $\mathbf{1 5}$ as a mixture of two diastereomers. Without separation, the mixture was treated with $\mathrm{Et}_{3} \mathrm{SiH} / \mathrm{BF}_{3} \cdot \mathrm{Et}_{2} \mathrm{O}\left(-78^{\circ} \mathrm{C}\right.$ to $\mathrm{rt}, 2 \mathrm{~h}$ ) [32] to yield the reductive dehydroxylation products 16 and 17 in a ratio of 98:2 (determined by ${ }^{1} \mathrm{H}$ NMR) [32] (combined yield: $88 \%$ over 2 steps), from which only the major product 16 was isolated (Scheme 6). For the chemoselective debenzylation, lithium naphthalenide (LN) was used [48]. To our disappointment, attempted cleavage of the benzyl group by LN (THF, $-40{ }^{\circ} \mathrm{C}$ to $\mathrm{rt}, 2 \mathrm{~h}$ ) gave the desired 18 in only $20 \%$ yield along with $60 \%$ of the recovered starting material 16 .

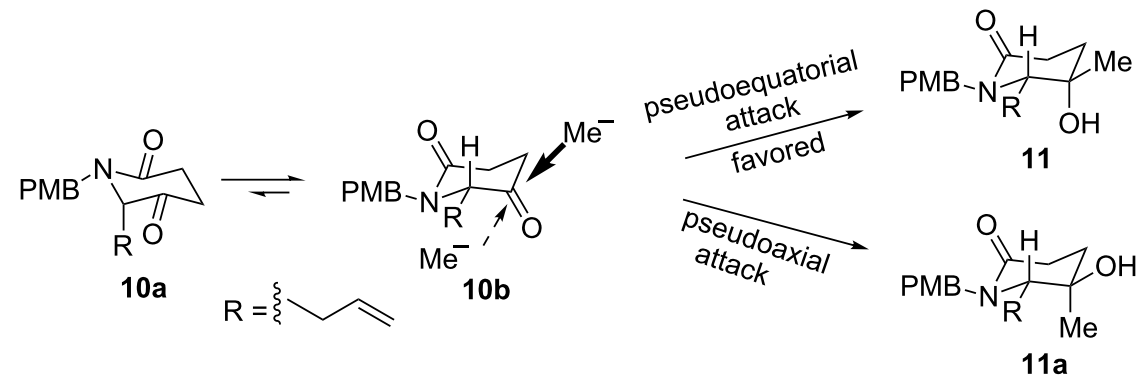

Scheme 4: Our plan for the trans-diastereoselective methylation of keto-lactam 10. 
<smiles>C=CC1(C)CCC(=O)N2CCCC21</smiles>

5<smiles>[R5][R15]([H])([H])N1C(=O)CC[C@](C)(O)[C@H]1CCC=C</smiles>

12

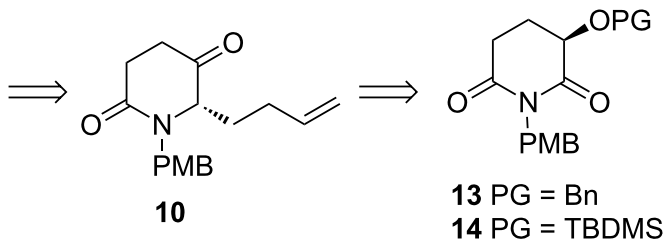

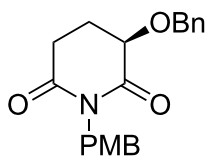

13

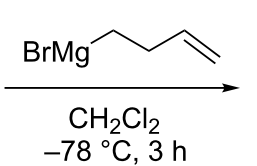

$-78^{\circ} \mathrm{C}, 3 \mathrm{~h}$<smiles>C=CCC[C@H]1C(OCc2ccccc2)CCC(=O)N1[13CH3]</smiles>

16<smiles>C=CCCC1(O)C(OCCCC)CCC(=O)N1P</smiles>

15

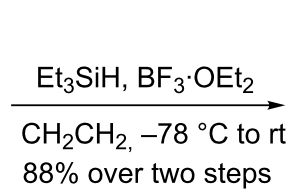

$$
\text { PMB }
$$<smiles>C=CCCC1C(OCCCC)CCC(=O)N1[18OH]</smiles>

$20 \%$ $\mathrm{LN}, \mathrm{THF}$ $-40{ }^{\circ} \mathrm{C}$ to rt

Scheme 6: Synthesis of compound 18

Due to the low yield in the debenzylation process, we decided to change the $O$-protecting group from benzyl to TBDMS, namely, use of TBDMS ether $\mathbf{1 4}$ as the starting material. Thus, (R)-3-(tert-butyldimethylsilyloxy)glutarimide 14 [49] was prepared from the known $(R)$-3-hydroxyglutarimide 19 (prepared from $(R)$-glutamic acid in $69 \%$ overall yield over 4 steps [47]) in a yield of $95 \%$. Successive treatment of imide 14 with 3-butenylmagnesium bromide $\left(\mathrm{CH}_{2} \mathrm{Cl}_{2},-20^{\circ} \mathrm{C}, 3 \mathrm{~h}\right)$ and the resulting hemi-aminal with $\mathrm{Et}_{3} \mathrm{SiH} / \mathrm{BF}_{3} \cdot \mathrm{Et}_{2} \mathrm{O}\left(\mathrm{CH}_{2} \mathrm{Cl}_{2}\right.$, $-78^{\circ} \mathrm{C}, 2 \mathrm{~h}$, then $-20^{\circ} \mathrm{C}, 2 \mathrm{~h}$ ) gave a diastereomeric mixture of lactams. Without separation, the mixture was treated with TBAF in dichloromethane to produce alcohols $\mathbf{1 8}$ and $\mathbf{2 0}$ (combined yield: $62 \%$ over 3 steps) in a ratio of 95:5 (determined by ${ }^{1} \mathrm{H}$ NMR), along with the keto-amide 21 in $13 \%$ yield (Scheme 7). Separation of the mixture by column chromatography gave pure diastereomer $\mathbf{1 8}$ in 59\% overall yield from $\mathbf{1 4}$. The trans-stereochemistry was tentatively assigned to compound $\mathbf{1 8}$ on the basis of our previous results, which was confirmed by the conversion of $\mathbf{1 8}$ into the known compound $\mathbf{5}$ (vide infra).

With lactam 18 in hand, its conversion to novel tertiary alcohol 22 was investigated. Oxidation of alcohol 18 with an excess of Dess-Martin periodinane (DMP) in dichloromethane at room temperature for $2 \mathrm{~h}$ proceeded smoothly to give ketone $\mathbf{1 0}$ in $93 \%$ yield. It is noteworthy that keto-lactam 10 is configurational labile, and should be used immediately in the next reaction. Treatment of keto-lactam 10 with MeMgI ( 3 equiv) in dichloromethane $\left(0{ }^{\circ} \mathrm{C}\right.$ to $\left.\mathrm{rt}, 12 \mathrm{~h}\right)$ gave a $76 \%$ yield of the desired methylation product $\mathbf{1 1}$ as the sole observable diastereomer (Scheme 8), whose stereochemistry was determined after converting into the known $(8 S, 8 \mathrm{a} S)-5$. This result verifies the previous assumption outlined in Scheme 4.

To remove the PMB protecting group, compound 11 was treated with ammonium cerium nitrate $(\mathrm{CAN})$ in $\mathrm{CH}_{3} \mathrm{CN} / \mathrm{H}_{2} \mathrm{O}$ 

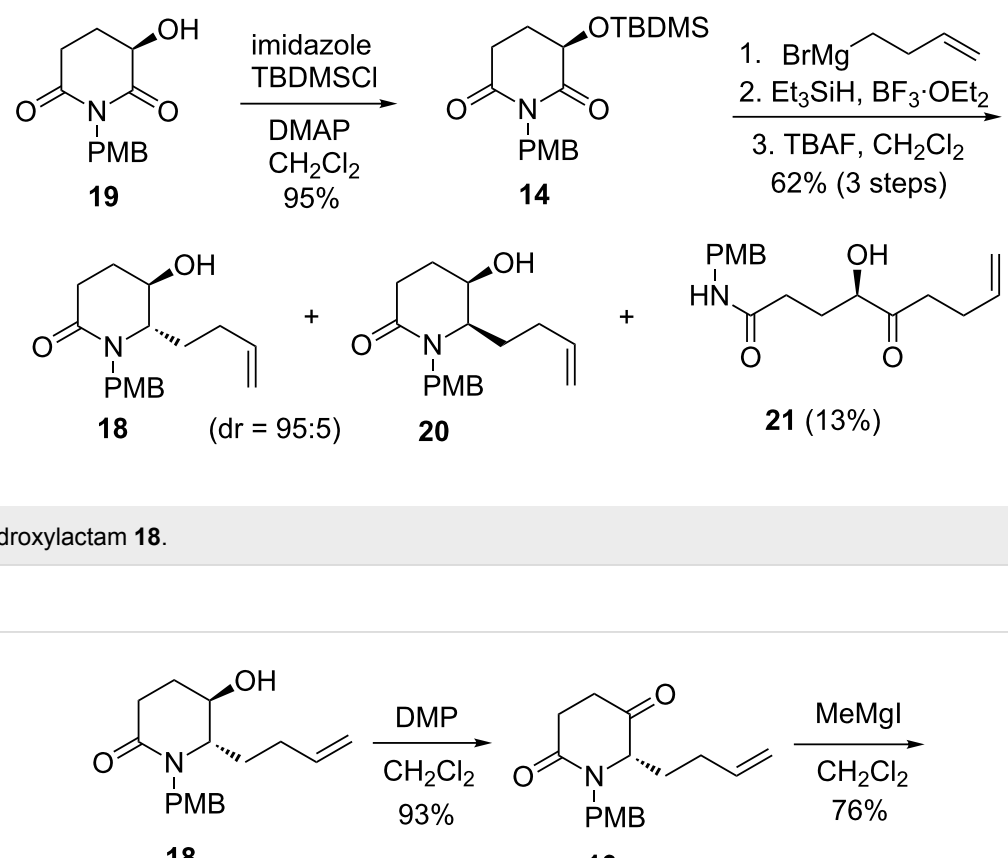

18

10<smiles>C=CCC1N([13CH3])C(=O)CCC1(C)O</smiles>

11

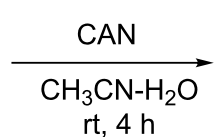

$56 \%$<smiles>C=CCC[C@H]1NC(=O)CCC1(C)O</smiles>

22

Scheme 8: Synthesis of tertiary alcohol 22.

(v/v 3:1) [50] at room temperature for $4 \mathrm{~h}$ to afford the deprotected lactam 22 in $56 \%$ yield.

Our next task was the oxidative cyclization of the olefin $\mathbf{2 2}$ to form the indolizidinone ring. Thus, ozonolysis of olefin 22 in dichloromethane [51], followed by quenching with $\mathrm{Me}_{2} \mathrm{~S}$ furnished the hemiaminal tautomer via intermediacy of lactamaldehyde. Without isolation, the crude was subjected to the reductive dehydroxylation with $\mathrm{Et}_{3} \mathrm{SiH} / \mathrm{BF}_{3} \cdot \mathrm{Et}_{2} \mathrm{O}\left(\mathrm{CH}_{2} \mathrm{Cl}_{2}\right.$, $-78{ }^{\circ} \mathrm{C}$ ) to give the desired indolizidinone $\mathbf{5}$ in an overall yield of $91 \%$ from 22 (Scheme 9).

The spectral data of the our synthetic $(8 S, 8 \mathrm{a} S)-\mathbf{5}$ are in agreement with those reported [12,22,27-29]. Due to the differences between the reported optical rotation values $\left\{[\alpha]_{\mathrm{D}}{ }^{20}-42.7\right.$ (c 1.0, $\left.\mathrm{CHCl}_{3}\right)$; lit. [12] $[\alpha]_{\mathrm{D}}{ }^{21}-47.0\left(c 0.97, \mathrm{CHCl}_{3}\right)$; lit. [22]<smiles>C=C[C@@H]1CC[C@@H]2N1C(=O)CC[C@]2(C)O</smiles>

22

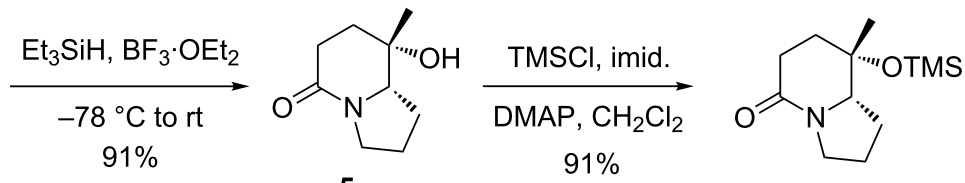


$[\alpha]_{\mathrm{D}}^{22}-55\left(c 0.79, \mathrm{CHCl}_{3}\right)$; lit. $[28][\alpha]_{\mathrm{D}}{ }^{25}-41.3(c 0.48$, $\left.\mathrm{CHCl}_{3}\right)$; lit. [29] $\left.[\alpha]_{\mathrm{D}}{ }^{25}-32.1\left(c 1.0, \mathrm{CHCl}_{3}\right)\right\}$, compound 5 was converted into the known silyl ether $\mathbf{2 3}$ (TMSCl, imidazole, DMAP, $\mathrm{CH}_{2} \mathrm{Cl}_{2}, 0{ }^{\circ} \mathrm{C}$ to rt, $24 \mathrm{~h}, 91 \%$ yield), which is identical in all aspects with that reported by Nubbemeyer $\left\{[\alpha]_{\mathrm{D}}{ }^{20}-35.3\right.$ (c 0.89, $\left.\mathrm{CHCl}_{3}\right)$; lit. [27] $\left.[\alpha]_{\mathrm{D}}{ }^{20}-35.1\left(c 1.08, \mathrm{CHCl}_{3}\right)\right\}$. Silyl ether $\mathbf{2 3}$ may serve as an advanced intermediate in the synthesis of pumiliotoxin 209F [17].

\section{Conclusion}

In summary, an eight-step synthesis of the advanced intermediate $(8 S, 8 \mathrm{a} S)-\mathbf{5}$ for the syntheis of pumiliotoxins has been achieved in $21 \%$ overall yield starting from $(R)$-3-silyloxyglutarimide derivative 14. The method is based on the versatile building block $\mathbf{1 4}$ and relied on a highly diastereoselective trans-addition of methylmagnesium iodide to keto-lactam $\mathbf{1 0}$ Since compound $(8 S, 8 \mathrm{a} S)-\mathbf{5}$ has been converted into pumiliotoxins 251D (2) and 237A (3), by Gallagher, Nubbemeyer, and Mori, respectively, its synthesis constitutes a formal enantioselective total synthesis of pumiliotoxins 251D and 237A. Compound $(8 S, 8 \mathrm{a} S)-\mathbf{5}$ would be of value for the synthesis of other pumiliotoxins as well. The highly diastereoselective trans-addition of a methylmagnesium iodide to keto-lactam $\mathbf{1 0}$ provides a new example of achieving the desired diastereoselection simply by the chair-conformation control $[52,53]$.

\section{Experimental}

Optical rotations were recorded on a Perkin-Elmer 341 automatic polarimeter. ${ }^{1} \mathrm{H}$ NMR and ${ }^{13} \mathrm{C}$ NMR spectra were recorded on bruker 400 spectrometer. ${ }^{1} \mathrm{H}$ NMR spectra were measured in $\mathrm{CDCl}_{3}$, and chemical shifts are expressed in parts per million (ppm) relative to internal $\mathrm{Me}_{4} \mathrm{Si}$. IR spectra were recorded on a Nicolet Avatar 330 RT-IR spectrophotometer. Mass spectra were recorded by Bruker Dalton Esquire 3000 plus and Finnigan Mat-LCQ (ESI direct injection). HRFABMS spectra were recorded on a Bruker APEX-FTMS apparatus. Elemental analyses were performed using a Vario RL analyzer. Melting points were determined on a Yanaco MP-500 melting point apparatus and are uncorrected.

Tetrahydrofuran (THF) was distilled prior to use from sodium benzophenone ketyl. Dichloromethane was distilled from phosphorus pentoxide. Silica gel (zhifu, 300-400 mesh) from Yantai silica gel factory (China) was used for column chromatography, eluting (unless otherwise stated) with ethyl acetate/petroleum ether $(\mathrm{PE})\left(60-90{ }^{\circ} \mathrm{C}\right)$ mixture.

(R)-3-(tert-Butyldimethylsilyloxy)-1-(4-methoxybenzyl)piperidine-2,6-dione (14): To a solution of $(R)-3$ hydroxy-1-(4-methoxybenzyl)piperidine-2,6-dione 19 [47] (125 mg, $0.5 \mathrm{mmol})$, DMAP (10 mg) and imidazole (67 mg,
$1 \mathrm{mmol})$ in $\mathrm{CH}_{2} \mathrm{Cl}_{2}(15 \mathrm{~mL})$ was added TBDMSCl $(52 \mu \mathrm{L}$, $0.6 \mathrm{mmol})$. The mixture was stirred at room temperature for $24 \mathrm{~h}$ before quenching with $\mathrm{H}_{2} \mathrm{O}(5 \mathrm{~mL})$. The organic layer was separated and the aqueous phase extracted with $\mathrm{CH}_{2} \mathrm{Cl}_{2}(10 \mathrm{~mL}$ $\times 5$ ). The combined organic layers were washed with brine, dried over anhydrous $\mathrm{Na}_{2} \mathrm{SO}_{4}$, filtered and concentrated under reduced pressure. The residue was purified by column chromatography on silica gel (EtOAc/hexane 1:2) to give silyl ether 14 (517 mg, yield: $95 \%)$ as a colorless oil. $[\alpha]_{\mathrm{D}}{ }^{20}+19.2(c 1.1$, $\mathrm{CHCl}_{3}$ ); IR (film) $v_{\text {max }}: 3062,2936,1728,1658,1494,1451$, $1367 \mathrm{~cm}^{-1} ;{ }^{1} \mathrm{H} \mathrm{NMR}\left(400 \mathrm{MHz}, \mathrm{CDCl}_{3}\right) \delta 0.11(\mathrm{~s}, 3 \mathrm{H}), 0.12(\mathrm{~s}$, $3 \mathrm{H}), 0.87$ (s, 9H), 1.92-2.07 (m, 2H), 2.59 (ddd, $J=17.7,7.5$, $5.4 \mathrm{~Hz}, 1 \mathrm{H}), 2.91(\mathrm{ddd}, J=17.7,8.1,5.4 \mathrm{~Hz}, 1 \mathrm{H}), 3.76(\mathrm{~s}, 3 \mathrm{H})$, 4.30 (dd, $J=7.4,4.0 \mathrm{~Hz}, 1 \mathrm{H}), 4.83(\mathrm{~d}, J=14.0 \mathrm{~Hz}, 1 \mathrm{H}), 4.86$ $(\mathrm{d}, J=14.0 \mathrm{~Hz}, 1 \mathrm{H}), 6.79(\mathrm{~d}, J=8.7 \mathrm{~Hz}, 2 \mathrm{H}), 7.30$ (d, $J=8.7$ $\mathrm{Hz}, 2 \mathrm{H}) ;{ }^{13} \mathrm{C} \mathrm{NMR}\left(100 \mathrm{MHz}, \mathrm{CDCl}_{3}\right) \delta-5.4,-4.7,18.2,25.6$ (3C), 26.4, 29.1, 42.4, 55.2, 69.3, 113.7 (2C), 129.4, 130.3 (2C), 158.9, 171.8, 172.2; HRMS ESI $(m / z):[\mathrm{M}+\mathrm{Na}]^{+}$calcd for $\mathrm{C}_{19} \mathrm{H}_{29} \mathrm{NO}_{4} \mathrm{SiNa}, 386.1758$; found, 386.1757 .

( $5 R, 6 S)$ - 6 - (B u t - 3 - enyl) - 5-hydroxy - 1 - (4 - meth oxybenzyl)piperidin-2-one (18): To a solution of compound 14 (2.8 g, $7.71 \mathrm{mmol})$ in anhydrous $\mathrm{CH}_{2} \mathrm{Cl}_{2}(100 \mathrm{~mL})$ at $-20{ }^{\circ} \mathrm{C}$ was added dropwise a freshly prepared 3-butenylmagnesium bromide (1 M in THF, $15 \mathrm{~mL}, 15 \mathrm{mmol}$ ). After being stirred at $-20{ }^{\circ} \mathrm{C}$ for $3 \mathrm{~h}$, the reaction was quenched with a saturated aqueous solution of $\mathrm{NH}_{4} \mathrm{Cl}(15 \mathrm{~mL})$. The organic layer was separated and the aqueous phase was extracted with $\mathrm{CH}_{2} \mathrm{Cl}_{2}$ $(25 \mathrm{~mL} \times 5)$. The combined organic layers were washed with brine $(10 \mathrm{~mL} \times 5)$, dried over anhydrous $\mathrm{Na}_{2} \mathrm{SO}_{4}$, filtered and concentrated under reduced pressure. Without further separation, the crude product $(2.4 \mathrm{~g}, 5.7 \mathrm{mmol})$ was treated with $\mathrm{Et}_{3} \mathrm{SiH}(9 \mathrm{~mL}, 57 \mathrm{mmol})$ and $\mathrm{BF}_{3} \cdot \mathrm{Et}_{2} \mathrm{O}(2.12 \mathrm{~mL}, 17.2 \mathrm{mmol})$ in $\mathrm{CH}_{2} \mathrm{Cl}_{2}(100 \mathrm{~mL})$ at $-78{ }^{\circ} \mathrm{C}$. The mixture was stirred at $-78{ }^{\circ} \mathrm{C}$ for $2 \mathrm{~h}$, and then allowed to warm to $-20{ }^{\circ} \mathrm{C}$. After being stirred for another $2 \mathrm{~h}$, saturated aqueous solution of $\mathrm{NaHCO}_{3}(25 \mathrm{~mL})$ was added and aqueous layer was extracted with $\mathrm{CH}_{2} \mathrm{Cl}_{2}(15 \mathrm{~mL} \times 5)$. The combined organic layers were washed with brine, dried over anhydrous $\mathrm{Na}_{2} \mathrm{SO}_{4}$, filtered and concentrated under reduced pressure to give a crude product, which was used in the next step without further purification. To a solution of the crude product in THF $(50 \mathrm{~mL})$ was added a $1 \mathrm{M}$ solution of TBAF in THF $(17.1 \mathrm{~mL}, 17.1 \mathrm{mmol})$ at $0{ }^{\circ} \mathrm{C}$. The mixture was allowed to warm to room temperature. After being stirred for $4 \mathrm{~h}$ at room temperature, the reaction was quenched with water, and extracted with $\mathrm{CH}_{2} \mathrm{Cl}_{2}(15 \mathrm{~mL} \times 5)$. The combined organic phases were washed with brine, dried over anhydrous $\mathrm{Na}_{2} \mathrm{SO}_{4}$, filtered and concentrated under reduced pressure. The residue was purified by column chromatography on silica gel (EtOAc/hexane 2:1) to give diastereomers 18 (969 mg, yield: 59\%) and 20 (51 mg, yield: 3\%). Com- 
pound 18: white solid, mp $102-105{ }^{\circ} \mathrm{C}\left(\right.$ EtOAc/hexane); $[\alpha]_{\mathrm{D}}{ }^{20}$ -65.0 (c 1.0, $\mathrm{CHCl}_{3}$ ); IR (film) $v_{\max }: 3375,2934,1612,1512$, 1193, 1056, 784, $560 \mathrm{~cm}^{-1}$; ${ }^{1} \mathrm{H}$ NMR $\left(400 \mathrm{MHz}, \mathrm{CDCl}_{3}\right) \delta$ $1.37-1.49(\mathrm{~m}, 1 \mathrm{H}), 1.67-1.64(\mathrm{~m}, 2 \mathrm{H}), 1.91-2.00(\mathrm{~m}, 2 \mathrm{H}), 2.28$ (ddd, $J=18.1,7.2,2.8 \mathrm{~Hz}, 1 \mathrm{H}), 2.58(\mathrm{ddd}, J=18.1,10.5,7.6$ $\mathrm{Hz}, 2 \mathrm{H}), 3.20$ (dt, $J=9.4,2.6 \mathrm{~Hz}, 1 \mathrm{H}), 3.72(\mathrm{~s}, 3 \mathrm{H}), 3.81$ (d, $J=$ $14.9 \mathrm{~Hz}, 1 \mathrm{H}), 3.93(\mathrm{dt}, J=4.6,2.6 \mathrm{~Hz}, 1 \mathrm{H}), 4.91-5.01(\mathrm{~m}, 2 \mathrm{H})$, $5.14(\mathrm{~d}, J=14.9 \mathrm{~Hz}, 1 \mathrm{H}), 5.69(\mathrm{ddt}, J=16.9,10.3,6.6 \mathrm{~Hz}, 1 \mathrm{H})$, $6.78(\mathrm{~d}, J=8.6 \mathrm{~Hz}, 2 \mathrm{H}), 7.15(\mathrm{~d}, J=8.6 \mathrm{~Hz}, 2 \mathrm{H}) ;{ }^{13} \mathrm{C} \mathrm{NMR}$ $\left(100 \mathrm{MHz}, \mathrm{CDCl}_{3}\right) \delta 23.9,26.7,30.0,31.3,47.3,55.1,61.8$, 65.0, 113.8 (2C), 115.5, 129.0, 129.1 (2C), 136.9, 158.7, 169.8; HRMS ESI $(m / z):[\mathrm{M}+\mathrm{Na}]^{+}$calcd for $\mathrm{C}_{17} \mathrm{H}_{23} \mathrm{NO}_{3} \mathrm{Na}$, 312.1570; found, 312.1570 .

(S)-6-(But-3-en-1-yl)-1-(4-methoxybenzyl)piperidine-2,5dione (10): To a stirred solution of compound 18 (100 mg, $0.34 \mathrm{mmol})$ in $\mathrm{CH}_{2} \mathrm{Cl}_{2}(5 \mathrm{~mL})$ was added Dess-Martin periodinane $(220 \mathrm{mg}, 0.52 \mathrm{mmol})$ at room temperature. After being stirred for $2 \mathrm{~h}$, the reaction was quenched with a $10 \%$ aqueous solution of $\mathrm{Na}_{2} \mathrm{~S}_{2} \mathrm{O}_{3}$. The aqueous phase was extracted with EtOAc $(15 \mathrm{~mL} \times 3)$. The combined organic layers were washed successively with a saturated aqueous solution of $\mathrm{NaHCO}_{3}$ $(5 \mathrm{~mL} \times 3)$ and brine $(5 \mathrm{~mL} \times 2)$. The combined organic phases were dried over $\mathrm{Na}_{2} \mathrm{SO}_{4}$, filtered and concentrated under reduced pressure. The residue was purified by column chromatography on silica gel (EtOAc/hexane 1:2) to give compound 10 (98 mg, yield: $93 \%$ ) as a colorless oil. $[\alpha]_{\mathrm{D}}{ }^{20}+37.5(c 1.0$, $\mathrm{CHCl}_{3}$ ); IR (film) $v_{\max }: 2955,2926,2834,1725,1625,1512$, 1246, 1173, $1032 \mathrm{~cm}^{-1}$; ${ }^{1} \mathrm{H}$ NMR (400 MHz, $\left.\mathrm{CDCl}_{3}\right) \delta$ 1.79-2.11 (m, 4H), 2.57-2.69 (m, 2H), 2.73-2.80 (m, 2H), 3.68 (dd, $J=7.5,4.6 \mathrm{~Hz}, 1 \mathrm{H}), 3.79(\mathrm{~s}, 3 \mathrm{H}), 3.85(\mathrm{~d}, J=14.7 \mathrm{~Hz}$, $1 \mathrm{H}), 4.97-5.08(\mathrm{~m}, 2 \mathrm{H}), 5.28(\mathrm{~d}, J=14.7 \mathrm{~Hz}, 1 \mathrm{H}), 5.70$ (ddt, $J$ $=16.7,10.2,6.4 \mathrm{~Hz}, 1 \mathrm{H}), 6.84(\mathrm{~d}, J=8.7 \mathrm{~Hz}, 2 \mathrm{H}), 7.15(\mathrm{~d}, J=$ $8.7 \mathrm{~Hz}, 2 \mathrm{H}) ;{ }^{13} \mathrm{C} \mathrm{NMR}\left(100 \mathrm{MHz}, \mathrm{CDCl}_{3}\right) \delta 29.0,29.2,30.6$, $35.3,47.2,55.2,63.9,114.2$ (2C), 116.3, 128.3, 129.5 (2C), 136.4, 159.3, 169.6, 206.2; HRMS ESI $(\mathrm{m} / \mathrm{z}):[\mathrm{M}+\mathrm{Na}]^{+}$calcd for $\mathrm{C}_{17} \mathrm{H}_{21} \mathrm{NO}_{3} \mathrm{Na}$, 310.1414; found, 310.1419 .

(5S,6S)-6-(But-3-enyl)-5-hydroxy-1-(4-methoxybenzyl)-5methylpiperidin-2-one (11): To a solution of compound $\mathbf{1 0}$ (92 mg, $0.32 \mathrm{mmol}$ ) in anhydrous $\mathrm{CH}_{2} \mathrm{Cl}_{2}(100 \mathrm{~mL})$ was added dropwise a freshly prepared $1 \mathrm{M}$ diethyl ether solution of $\mathrm{CH}_{3} \mathrm{MgI}(1.0 \mathrm{~mL}, 1.0 \mathrm{mmol})$ at $0{ }^{\circ} \mathrm{C}$. After being stirred at room temperature overnight, the reaction was quenched with a saturated aqueous solution of $\mathrm{NH}_{4} \mathrm{Cl}(5 \mathrm{~mL})$. The organic layer was separated and the aqueous phase was extracted with $\mathrm{CH}_{2} \mathrm{Cl}_{2}(15 \mathrm{~mL} \times 5)$. The combined organic layers were washed with brine, dried over anhydrous $\mathrm{Na}_{2} \mathrm{SO}_{4}$, filtered and concentrated under reduced pressure. The residue was purified by column chromatography on silica gel (EtOAc/hexane 1:1) to give compound 11 (75 mg, yield: $76 \%$ ) as a colorless oil. $[\alpha]_{\mathrm{D}}{ }^{20}$
-73.5 (c 1.0, $\mathrm{CHCl}_{3}$ ); IR (film) v $v_{\max }: 3378,2928,2925,2874$, 1612, 1512, 1247, 1150, 1034, 914, $847 \mathrm{~cm}^{-1} ;{ }^{1} \mathrm{H}$ NMR (400 $\left.\mathrm{MHz}, \mathrm{CDCl}_{3}\right) \delta 0.99(\mathrm{~s}, 3 \mathrm{H}), 1.57-1.65(\mathrm{~m}, 2 \mathrm{H}), 1.73(\mathrm{~d}, J=$ $16.5 \mathrm{~Hz}, 1 \mathrm{H}), 2.04-2.12(\mathrm{~m}, 2 \mathrm{H}), 2.20-2.27$ (m, 2H), 2.41 (ddd, $J=18.6,9.5,8.8 \mathrm{~Hz}, 1 \mathrm{H}), 2.55(\mathrm{ddd}, J=18.6,8.8,2.2 \mathrm{~Hz}, 1 \mathrm{H})$, $3.00(\mathrm{td}, J=5.4,1.6 \mathrm{~Hz}, 1 \mathrm{H}), 3.59(\mathrm{~d}, J=14.3 \mathrm{~Hz}, 1 \mathrm{H}), 3.78$ (s, $3 \mathrm{H}), 5.00-5.10(\mathrm{~m}, 2 \mathrm{H}), 5.45$ (d, $J=14.3 \mathrm{~Hz}, 1 \mathrm{H}), 5.81$ (ddt, $J$ $=16.8,10.2,6.7 \mathrm{~Hz}, 1 \mathrm{H}), 6.83(\mathrm{~d}, J=8.6 \mathrm{~Hz}, 2 \mathrm{H}), 7.20(\mathrm{~d}, J=$ $8.6 \mathrm{~Hz}, 2 \mathrm{H}) ;{ }^{13} \mathrm{C} \mathrm{NMR}\left(100 \mathrm{MHz}, \mathrm{CDCl}_{3}\right) \delta 26.9,29.0,30.5$, $30.8,32.5,48.6,55.2,63.1,70.1,113.8$ (2C), 115.5, 129.0, $130.4(2 \mathrm{C}), 138.0,159.1,168.7$; HRMS ESI $(m / z):[\mathrm{M}+\mathrm{Na}]^{+}$ calcd for $\mathrm{C}_{18} \mathrm{H}_{25} \mathrm{NO}_{3} \mathrm{Na}, 326.1727$; found, 326.1728.

(5S,6S)-6-(But-3-enyl)-5-hydroxy-5-methylpiperidin-2-one (22): To a solution of compound $\mathbf{1 1}(463 \mathrm{mg}, 1.52 \mathrm{mmol})$ in a mixture of $\mathrm{CH}_{3} \mathrm{CN}(32 \mathrm{~mL})$ and $\mathrm{H}_{2} \mathrm{O}(11 \mathrm{~mL})$ was added ammonium cerium nitrate $(2.5 \mathrm{~g}, 4.56 \mathrm{mmol})$ in one portion. The mixture was stirred for $4 \mathrm{~h}$ at room temperature. To the resulting mixture was added $\mathrm{H}_{2} \mathrm{O}(5 \mathrm{~mL})$, and the mixture was extracted with EtOAc $(30 \mathrm{~mL} \times 5)$. The combined organic layers were washed successively with a saturated solution aqueous of $\mathrm{NaHCO}_{3}$ and brine. The organic phases were dried over anhydrous $\mathrm{Na}_{2} \mathrm{SO}_{4}$, filtered and concentrated under reduced pressure. The residue was purified by column chromatography on silica gel $\left(\mathrm{MeOH} / \mathrm{CH}_{2} \mathrm{Cl}_{2}\right.$ 1:40) to give compound 22 (153 mg, yield: $56 \%$ ) as a pale yellow oil. $[\alpha]_{\mathrm{D}}{ }^{20}-43.0(c$ $1.18, \mathrm{CHCl}_{3}$ ); IR (film) $v_{\max }$ : 3366, 2932, 1612, 1475, 1406, $1312,919 \mathrm{~cm}^{-1}$; ${ }^{1} \mathrm{H}$ NMR $\left(400 \mathrm{MHz}, \mathrm{CDCl}_{3}\right) \delta 1.31(\mathrm{~s}, 3 \mathrm{H})$, $1.52-1.61(\mathrm{~m}, 1 \mathrm{H}), 1.76-1.93(\mathrm{~m}, 3 \mathrm{H}), 2.10(\mathrm{~m}, 1 \mathrm{H}), 2.22-2.35$ (m, 2H), 2.57 (ddd, $J=18.2,11.1,7.0 \mathrm{~Hz}, 1 \mathrm{H}), 2.80(\mathrm{~s}, 1 \mathrm{H}$, $\mathrm{OH}, \mathrm{D}_{2} \mathrm{O}$ exchangeable), $3.17(\mathrm{dd}, J=10.2,1.8 \mathrm{~Hz}, 1 \mathrm{H})$, 5.03-5.12 (m, 2H), 5.79 (ddt, $J=17.0,10.2,6.6 \mathrm{~Hz}, 1 \mathrm{H}), 6.03$ $(\mathrm{s}, 1 \mathrm{H}, \mathrm{NH}) ;{ }^{13} \mathrm{C} \mathrm{NMR}\left(100 \mathrm{MHz}, \mathrm{CDCl}_{3}\right) \delta 26.3,27.5,28.7$, 30.0, 34.1, 60.1, 67.9, 115.9, 137.1, 172.4; HRMS ESI $(\mathrm{m} / \mathrm{z})$ : $[\mathrm{M}+\mathrm{Na}]^{+}$calcd for $\mathrm{C}_{10} \mathrm{H}_{17} \mathrm{NO}_{2} \mathrm{Na}, 206.1151$; found, 206.1160 .

(8S,8aS)-8-Hydroxy-8-methyloctahydroindolizidin-5-one (5): To a stirred solution of compound $22(90 \mathrm{mg}, 0.49 \mathrm{mmol})$ in a mixture of $\mathrm{CH}_{2} \mathrm{Cl}_{2}(8 \mathrm{~mL})$ and $\mathrm{MeOH}(2 \mathrm{~mL})$ was bubbled $\mathrm{O}_{3}$ at $-78^{\circ} \mathrm{C}$ for $10 \mathrm{~min}$. The reaction was quenched with $\mathrm{Me}_{2} \mathrm{~S}$ $(0.2 \mathrm{~mL})$. The mixture was allowed to warm to room temperature. The organic layer was separated, and the aqueous phase was extracted with $\mathrm{CH}_{2} \mathrm{Cl}_{2}(15 \mathrm{~mL} \times 5)$. The combined organic layers were washed with brine, dried over anhydrous $\mathrm{Na}_{2} \mathrm{SO}_{4}$, filtered and concentrated under reduced pressure. Without further purification, to a solution of the crude mixture in $\mathrm{CH}_{2} \mathrm{Cl}_{2}(5 \mathrm{~mL})$ was added $\mathrm{Et}_{3} \mathrm{SiH}(0.77 \mathrm{~mL}, 4.9 \mathrm{mmol})$ and $\mathrm{BF}_{3} \cdot \mathrm{Et}_{2} \mathrm{O}(0.18 \mathrm{~mL}, 1.47 \mathrm{mmol})$ at $-78{ }^{\circ} \mathrm{C}$. The mixture was allowed to warm slowly to the room temperature. A saturated aqueous solution of $\mathrm{NaHCO}_{3}(2 \mathrm{~mL})$ was added and aqueous 
phase was extracted with $\mathrm{CH}_{2} \mathrm{Cl}_{2}(15 \mathrm{~mL} \times 5)$. The combined organic layers were washed with brine, dried over anhydrous $\mathrm{Na}_{2} \mathrm{SO}_{4}$, filtered and concentrated under reduced pressure. The residue was purified by column chromatography on silica gel $\left(\mathrm{MeOH} / \mathrm{CH}_{2} \mathrm{Cl}_{2}\right.$ 1:20) to give compound 5 (75 mg, yield: 91\%) as a colorless waxy solid. $[\alpha]_{\mathrm{D}}{ }^{20}-42.7\left(c 1.0, \mathrm{CHCl}_{3}\right)\{$ lit. [12] $[\alpha]_{\mathrm{D}}{ }^{20}-47.0\left(c 0.8, \mathrm{CHCl}_{3}\right)$ lit. [28] $[\alpha]_{\mathrm{D}}{ }^{25}-41.3($ c 0.48 , $\mathrm{CHCl}_{3}$ ); lit. [29] $\left.[\alpha]_{\mathrm{D}}^{25}-32.1\left(c 1.0, \mathrm{CHCl}_{3}\right)\right\}$; IR (film) $v_{\max }$ : 3364, 2926, 2877, 1612, 1469, 1265, 740, $703 \mathrm{~cm}^{-1}$; ${ }^{1} \mathrm{H} \mathrm{NMR}$ $\left(400 \mathrm{MHz}, \mathrm{CDCl}_{3}\right) \delta 1.29(\mathrm{~s}, 3 \mathrm{H}), 1.74-1.97(\mathrm{~m}, 6 \mathrm{H}), 2.20(\mathrm{br}$ s, $1 \mathrm{H}, \mathrm{OH}, \mathrm{D}_{2} \mathrm{O}$ exchangeable), $2.38(\mathrm{dd}, J=18.4,7.4 \mathrm{~Hz}, 1 \mathrm{H})$, $2.53(\mathrm{ddd}, J=18.4,11.7,7.4 \mathrm{~Hz}, 1 \mathrm{H}), 3.35(\mathrm{dd}, J=10.3,5.3$ $\mathrm{Hz}, 1 \mathrm{H}), 3.48-3.53(\mathrm{~m}, 2 \mathrm{H}) ;{ }^{13} \mathrm{C} \mathrm{NMR}\left(100 \mathrm{MHz}, \mathrm{CDCl}_{3}\right) \delta$ 22.0, 26.3, 26.4, 28.0, 35.1, 45.7, 66.1, 67.7, 169.0; HRMS ESI $(m / z):[\mathrm{M}+\mathrm{Na}]^{+}$calcd for $\mathrm{C}_{9} \mathrm{H}_{15} \mathrm{NO}_{2} \mathrm{Na}, 192.0995$; found, 192.0999 .

(8S,8aS)-8-Methyl-8-trimethylsilyloxyoctahydroindolizidin5-one (23): $\mathrm{TMSCl}(25 \mu \mathrm{L}, 0.28 \mathrm{mmol})$ was added a solution of compound 5 (40 mg, $0.24 \mathrm{mmol}$ ), DMAP ( $5 \mathrm{mg}$ ) and imidazole (32 mg, $0.48 \mathrm{mmol})$ in $\mathrm{CH}_{2} \mathrm{Cl}_{2}\left(8 \mathrm{~mL}\right.$ ) at $0{ }^{\circ} \mathrm{C}$. The mixture was stirred at room temperature for $24 \mathrm{~h}$, and then diluted with $\mathrm{H}_{2} \mathrm{O}$ $(2 \mathrm{~mL})$. The organic layer was separated and the aqueous phase was extracted with $\mathrm{CH}_{2} \mathrm{Cl}_{2}(5 \mathrm{~mL} \times 5)$. The combined organic layers were washed with brine, dried over anhydrous $\mathrm{Na}_{2} \mathrm{SO}_{4}$, filtered and concentrated under reduced pressure. The residue was purified by column chromatography on silica gel (EtOAc/ hexane 1:2) to give compound $\mathbf{2 3}$ (53 $\mathrm{mg}$, yield: $91 \%$ ) as a pale yellow oil. $[\alpha]_{\mathrm{D}}{ }^{20}-35.3\left(c 0.89, \mathrm{CHCl}_{3}\right)\left\{\right.$ lit. [27] $[\alpha]_{\mathrm{D}}{ }^{20}-35.1$ (c 1.08, $\left.\left.\mathrm{CHCl}_{3}\right)\right\}$; IR (film) $v_{\max }: 2955,2880,1621,1470$, $1413,1378,1316,1273,1265,1253,1224,1134,1068,1021$ $\mathrm{cm}^{-1} ;{ }^{1} \mathrm{H}$ NMR $\left(400 \mathrm{MHz}, \mathrm{CDCl}_{3}\right) \delta 0.05(\mathrm{~s}, 9 \mathrm{H}), 1.26(\mathrm{~s}, 3 \mathrm{H})$, $1.60-1.90(\mathrm{~m}, 6 \mathrm{H}), 2.25-2.33(\mathrm{~m}, 1 \mathrm{H}), 2.33-2.45(\mathrm{~m}, 1 \mathrm{H})$, $3.15-3.20(\mathrm{dd}, J=10.0,5.5 \mathrm{~Hz}, 1 \mathrm{H}), 3.38-3.48(\mathrm{~m}, 2 \mathrm{H})$; ${ }^{13} \mathrm{C}$ NMR $\left(100 \mathrm{MHz}, \mathrm{CDCl}_{3}\right) \delta 2.1,21.9,26.2,26.3,28.2$, 35.2, 45.7, 67.3, 70.4, 168.9; HRMS ESI $(\mathrm{m} / \mathrm{z}):[\mathrm{M}+\mathrm{Na}]^{+}$ calcd for $\mathrm{C}_{12} \mathrm{H}_{23} \mathrm{NO}_{2} \mathrm{SiNa}, 264.1390$; found, 264.1392.

\section{Supporting Information}

$$
\begin{aligned}
& \text { Supporting Information File } 1 \\
& { }^{1} \mathrm{H} \text { and }{ }^{13} \mathrm{C} \text { NMR of key compounds. } \\
& \text { [http://www.beilstein-journals.org/bjoc/content/ } \\
& \text { supplementary/1860-5397-9-271-S1.pdf] }
\end{aligned}
$$

\section{Acknowledgments}

The authors are grateful to National Basic Research Program (973 Program) of China (Grant No. 2010CB833200), the NSF of China (21072160; 21332007), and the Program for Changjiang Scholars and Innovative Research Team in Univer- sity (PCSIRT) of Ministry of Education, China for financial support. We thank Mr. Xin Li for the initial work displayed in Scheme 1.

\section{References}

1. Daly, J. W.; Spande, T. F.; Garraffo, H. M. J. Nat. Prod. 2005, 68, 1556-1575. doi:10.1021/np0580560

2. Vandendriessche, T.; Abdel-Mottaleb, Y.; Maertens, C.; Cuypers, E.; Sudau, A.; Nubbemeyer, U.; Mebs, D.; Tytgat, J. Toxicon 2008, 51, 334-344. doi:10.1016/j.toxicon.2007.10.011

3. Daly, J. W.; Gusovsky, F.; McNeal, E. T.; Secunda, S.; Bell, M.; Creveling, C. R.; Nichizawa, Y.; Overman, L. E.; Sharp, M. J.; Rossignol, D. P. Biochem. Pharmacol. 1990, 40, 315-326. doi:10.1016/0006-2952(90)90694-G

4. Smith, S. Q.; Jones, T. H. Proc. Natl. Acad. Sci. U. S. A. 2004, 101, 7841-7842. doi:10.1073/pnas.0402599101

5. Saporito, R. A.; Garraffo, H. M.; Donnelly, M. A.; Edwards, A. L.; Longino, J. T.; Daly, J. W. Proc. Natl. Acad. Sci. U. S. A. 2004, 101 , 8045-8050. doi:10.1073/pnas.0402365101

6. Takada, W.; Sakata, T.; Shimano, S.; Enami, Y.; Mori, N.; Nishida, R.; Kuwahara, Y. J. Chem. Ecol. 2005, 31, 2403-2415. doi:10.1007/s10886-005-7109-9

7. Kibayashi, C. Chem. Pharm. Bull. 2005, 53, 1375-1386. doi:10.1248/cpb.53.1375

8. Tang, B. C.; Li, W. D. Chin. J. Org. Chem. 2004, 24, 1151-1158.

9. Franklin, A. S.; Overman, L. E. Chem. Rev. 1996, 96, 505-522. doi:10.1021/CR950021P

10. Daly, J. W.; Tokuyama, T.; Fujiwara, T.; Higher, R. J.; Karlet, I. L. J. Am. Chem. Soc. 1980, 102, 830-836. doi:10.1021/ja00522a064

11. Overman, L. E.; Bell, K. L. J. Am. Chem. Soc. 1981, 103, 1851-1853. doi:10.1021/ja00397a052

12. Fox, D. N. A.; Lathbury, D.; Mahon, M. F.; Molloy, K. C.; Gallagher, T. J. Am. Chem. Soc. 1991, 113, 2652-2656. doi:10.1021/ja00007a044

13. Pinho, V. D.; Procter, D. J.; Burtoloso, A. C. B. Org. Lett. 2013, 15 , 2434-2437. doi:10.1021/ol400903n

14. Bernardim, B.; Pinho, V. D.; Burtoloso, A. C. B. J. Org. Chem. 2012, 77, 9926-9931. doi:10.1021/jo301967w

15. Sultane, P. R.; Mohite, A. R.; Bhat, R. G. Tetrahedron Lett. 2012, 53, 5856-5858. doi:10.1016/j.tetlet.2012.08.061

16. Woodin, K. S.; Jamison, T. F. J. Org. Chem. 2007, 72, 7451-7454 doi:10.1021/jo071132e

17. Sudau, A.; Münch, W.; Bats, J. W.; Nubbemeyer, U. Eur. J. Org. Chem. 2002, 3315-3325.

doi:10.1002/1099-0690(200210)2002:19<3315::AID-EJOC3315>3.0.C $\mathrm{O} ; 2-2$

18. Ni, Y.; Zhao, G.; Ding, Y. J. Chem. Soc., Perkin Trans. 12000, 3264-3266. doi:10.1039/b004450o

19. Barrett, A. G. M.; Damiani, F. J. Org. Chem. 1999, 64, 1410-1411. doi:10.1021/jo9820972

20. Cossy, J.; Cases, M.; Gomez Pardo, D. Bull. Soc. Chim. Fr. 1997, 134, 141-144.

21. Cossy, J.; Cases, M.; Gomez Pardo, D. Synlett 1996, 909-910. doi:10.1055/s-1996-5590

22. Martin, S. F.; Bur, S. K. Tetrahedron 1999, 55, 8905-8914. doi:10.1016/S0040-4020(99)00452-4

23. Bargar, T. M.; Lett, R. M.; Johnson, P. L.; Hunter, J. E.; Chang, C. P.; Pernich, D. J.; Sabol, M. R.; Dick, M. R. J. Agric. Food Chem. 1995, 43, 1044-1051. doi:10.1021/jf00052a037 
24. Honda, T.; Hoshi, M.; Kanai, K.; Tsubuki, M. J. Chem. Soc., Perkin Trans. 1 1994, 2091-2101. doi:10.1039/p19940002091

25. Honda, T.; Hoshi, M.; Tsubuki, M. Heterocycles 1992, 34, 1515-1518. doi:10.3987/COM-92-6098

26. Overman, L. E.; Bell, K. L.; Ito, F. J. Am. Chem. Soc. 1984, 106, 4192-4201. doi:10.1021/ja00327a022

27. Sudau, A.; Münch, W.; Bats, J. W.; Nubbemeyer, U. Eur. J. Org. Chem. 2002, 3304-3314. doi:10.1002/1099-0690(200210)2002:19<3304::AID-EJOC3304>3.0.C $\mathrm{O} ; 2-\mathrm{A}$

28. Wu, H.; Yu, M.; Zhang, Y.; Zhao, G. Chin. J. Chem. 2009, 27, 183-188. doi:10.1002/cjoc.200990015

29. O'Mahony, G.; Nieuwenhuyzen, M.; Armstrong, P.; Stevenson, P. J. J. Org. Chem. 2004, 69, 3968-3971. doi:10.1021/jo0497205

30. Chen, B.-F.; Tasi, M.-R.; Yang, C.-Y.; Chang, J.-K.; Chang, N.-C. Tetrahedron 2004, 60, 10223-10231. doi:10.1016/j.tet.2004.09.001

31. Wang, B.; Fang, F.; Lin, G.-Q. Tetrahedron Lett. 2003, 44, 7981-7984. doi:10.1016/j.tetlet.2003.08.113

32. Huang, P.-Q. Synlett 2006, 1133-1149. doi:10.1055/s-2006-941565 See for an account on the methodology of the regio-and trans-diastereoselective reductive addition of glutarimide.

33. Liu, X.-K.; Ye, J.-L.; Ruan, Y.-P.; Li, Y.-X.; Huang, P.-Q. J. Org. Chem. 2013, 78, 35-41. doi:10.1021/jo3014484

34. Huo, H.-H.; Xia, X.-E.; Zhang, H.-K.; Huang, P.-Q. J. Org. Chem. 2013, 78, 455-465. doi:10.1021/jo302362b

35. Liu, X.-K.; Zheng, X.; Ruan, Y.-P.; Ma, J.; Huang, P.-Q. Org. Biomol. Chem. 2012, 10, 1275-1284. doi:10.1039/c1ob06697h

36. Zhuang, J.-J.; Ye, J.-L.; Zhang, H.-K.; Huang, P.-Q. Tetrahedron 2012, 68, 1750-1755. doi:10.1016/j.tet.2011.12.063

37. Liu, X.-K.; Qiu, S.; Xiang, Y.-G.; Ruan, Y.-P.; Zheng, X.; Huang, P.-Q. J. Org. Chem. 2011, 76, 4952-4963. doi:10.1021/jo200600n

38. Zhang, H.-K.; Li, X.; Huang, H.; Huang, P.-Q. Sci. China: Chem. 2011, 54, 737-744. doi:10.1007/s11426-011-4256-4

39. Wu, Y. D.; Houk, K. N.; Florez, J.; Trost, B. M. J. Org. Chem. 1991, 56, 3656-3664. doi:10.1021/jo00011a039

40. Ashby, E. C.; Laemmle, J. T. Chem. Rev. 1975, 75, 521-546. doi:10.1021/cr60296a005

41. Trost, B. M.; Florez, J.; Jebaratnam, D. J. J. Am. Chem. Soc. 1987, 109, 613-615. doi:10.1021/ja00236a067

42. Huang, P. Q.; Zhou, W. S. Tetrahedron: Asymmetry 1991, 2, 875-878. doi:10.1016/S0957-4166(00)82199-0

43. Dimitrov, V.; Panev, S. Tetrahedron: Asymmetry 2000, 11, 1513-1516. doi:10.1016/S0957-4166(00)00099-9

44. Tan, C.-H.; Holmes, A. B. Chem.-Eur. J. 2001, 7, 1845-1854. doi:10.1002/1521-3765(20010504)7:9<1845::AID-CHEM1845>3.0.CO; $2-2$

45. Liu, L.-X.; Xiao, K.-J.; Huang, P.-Q. Tetrahedron 2009, 65, 3834-3841. doi:10.1016/j.tet.2009.03.021

46. Liu, L.-X.; Ruan, Y.-P.; Guo, Z.-Q.; Huang, P.-Q. J. Org. Chem. 2004, 69, 6001-6009. doi:10.1021/jo049166z

47. Yu, D.-S.; Xu, W.-X.; Liu, L.-X.; Huang, P.-Q. Synlett 2008, 1189-1192. doi:10.1055/s-2008-1072737

48. Liu, H.-J.; Yip, J.; Shia, K.-S. Tetrahedron Lett. 1997, 38, 2253-2256. doi:10.1016/s0040-4039(97)00345-6

49. Huang, P.-Q.; Wei, B.-G.; Ruan, Y.-P. Synlett 2003, 1663-1667. doi:10.1055/s-2003-40988

50. Fukuyama, T.; Frank, R. K.; Jewell, C. F., Jr. J. Am. Chem. Soc. 1980, 102, 2122-2123. doi:10.1021/ja00526a076
51. Smith, A. B., III; Wang, Z. J. Org. Chem. 2000, 65, 3738-3753. doi:10.1021/jo991958j

52. Tuo, S.; Liu, X.; Huang, P. Chin. J. Chem. 2013, 31, 55-62. doi:10.1002/cjoc.201200904

53. Wang, Y.-H.; Ou, W.; Xie, L.-F.; Ye, J.-L.; Huang, P.-Q. Asian J. Org. Chem. 2012, 1, 359-365. doi:10.1002/ajoc.201200113 See for part I of this series.

\section{License and Terms}

This is an Open Access article under the terms of the Creative Commons Attribution License

(http://creativecommons.org/licenses/by/2.0), which permits unrestricted use, distribution, and reproduction in any medium, provided the original work is properly cited.

The license is subject to the Beilstein Journal of Organic Chemistry terms and conditions:

(http://www.beilstein-journals.org/bjoc)

The definitive version of this article is the electronic one which can be found at: doi:10.3762/bjoc.9.271 